\title{
Ligation of Processus Vaginalis During Orchidopexy: Is It Mandatory?
}

\author{
Khan $\mathrm{FA}^{1}$, Maharjan $\mathrm{P}^{1}$
}

\begin{abstract}
Introduction: Undescended testis is one of the commonest presentations in pediatric population. Conventionally, high ligation of the hernia sac was done after vas and vessels were dissected in order to prevent post-operative hernia. However, recent studies have shown that hernia sac ligation was unnecessary. Aims: To evaluate the role of hernia sac ligation during orchidopexy to prevent the development of postoperative hernia and to compare the mean operative time with and without sac ligation. Methods: A prospective comparative study was conducted with a total of 94 patients with undescended testis, age ranging from six months to 16 years were included in the study from November 2018 to May 2021. Cases were randomly divided into two groups. In Group A cases, orchidopexy was carried out with sac ligation, while in Group B, the hernia sac was not ligated. Mean operative time was recorded in each case. All the patients were followed up at one, four and eight weeks post-operatively and examined for postoperative hernia. Results: Of the total 94 cases, there were 18 bilateral and 76 unilateral cases of which 56 were right-sided and 22 left-sided. Most of the patients (45) of the study were between six months and 2 years. None of the patients of either group developed post-operative hernia or any significant complications. The mean operative time for group A and B were 36.72 and 46.96 minutes respectively. Conclusion: It was concluded that ligation of processus vaginalis was unnecessary during orchidopexy and sac ligation consumed more operative time.
\end{abstract}

Keywords: Orchidopexy, Post-operative hernia, Processus vaginalis, Undescended testis

\section{Authors:}

1. Dr. Feeroz Alam Khan

2. Dr. Prabir Maharjan

${ }^{1}$ Department of Pediatric Surgery, Nepalgunj Medical College and Teaching Hospital,Kohalpur, Banke

\section{Address for Correspondence:}

Dr. Feeroz Alam Khan

Lecturer

Department of Pediatric Surgery

Nepalgunj Medical College and Teaching Hospital

Kohalpur, Banke

Email: feeroze880@gmail.com

\section{INTRODUCTION}

Undescended testis is best described as a testis that cannot be brought down to the bottom of scrotum without undue traction on the spermatic cord. ${ }^{1}$ It is one of the most common condition presenting in pediatric surgical outpatient department. It is prevalent in about one to four and a half percentage of newborns with a higher incidence in preterm babies (30-45\%). 2,3 Studies suggest there is probability of spontaneous decent in the first three months post natally, beyond which it was rare. ${ }^{4-6}$ The recommended age for surgery for undescended testis is six months of age..$^{7-10}$

Undescended testis maybe unilateral or bilateral, mostly affecting the right side (70\%). Based on the testicular location, undescended testis is classified as those which maybe either along the normal line of descent or in ectopic position. ${ }^{2}$ About $80 \%$ of undescended testis are palpable and are found in superficial inguinal pouch (30\%), in the inguinal canal (20\%), upper part of scrotum (45\%) and in the perineum or thigh (five percent). About $20 \%$ of undescended testis are non-palpable and are located in the abdominal cavity. ${ }^{11}$

Conventionally, high ligation of the hernia sac at the deep ring was done after the testicular vessels and vas deferens were dissected in order to prevent post-operative hernia. This study was carried out to see if ligation of hernial sac was actually required to prevent post-operative hernia in the setting of orchidopexies.

\section{METHODS}

This prospective comparative study was conducted between November 2018 and May 2021 in the department of Pediatric Surgery, Nepalgunj Medical College and Teaching Hospital, Kohalpur. Ninety four children with an age range of six months to 16 years with a diagnosis of undescended testis were included in the study. Only those cases were included in which the testis was palpable and there was no associated clinical hernia. Baseline investigations were done and informed written 
consent was obtained from the parents after explaining the procedure in detail. The ethical clearance was obtained from the Institutional Review Board of Nepalgunj Medical College and Teaching Hospital. The cases were randomly divided into two groups. Group A cases underwent orchidopexies with ligation of hernia sac, while in Group B cases, sac ligation was not done. All the surgeries were performed by the researcher himself. Demographic information regarding name, age, gender, parents name, address, contact number was recorded in a Performa. Operative time was noted for each case. Operative time was interpreted as the time from incision till the skin closure, excluding the induction and recovery from anaesthesia.

All the patients were discharged on the first post-operative day and followed on one, four and eight weeks. Patients were examined for post-operative hernia during each follow-up and the results were noted.

\section{RESULTS}

In the study, 46(48.9\%) patients underwent ligation of sac while in $48(51.1 \%)$ patients hernial sac was not ligated.

\begin{tabular}{|c|c|c|c|c|}
\hline \multirow[t]{2}{*}{ Laterality } & \multicolumn{2}{|c|}{ Group } & \multirow{2}{*}{ Total } & \multirow{2}{*}{$\begin{array}{l}\text { Pearson Chi- } \\
\text { Square } \\
\text { (P value) }\end{array}$} \\
\hline & Group A & Group B & & \\
\hline Left & 7 & 13 & 20 & \multirow[b]{4}{*}{0.147} \\
\hline Right & 27 & 29 & 56 & \\
\hline Bilateral & 12 & 6 & 18 & \\
\hline Total & 46 & 48 & 94 & \\
\hline
\end{tabular}

Table I: Laterality and ligation of processus vaginalis

There were $76(80.8 \%)$ patients with unilateral undescended testis with 20(26.3\%) left sided and 56(73.3\%) right sided presentation while $18(19.2 \%)$ patients had bilateral undescended testis. The results were not statistically significant ( $p$ value 0.147 )

\begin{tabular}{|ccccc|}
\hline \multicolumn{1}{|c}{ Age } & \multicolumn{2}{c}{ Group } & Total & $\begin{array}{c}\text { Pearson Chi- } \\
\text { Square } \\
\text { (P value) }\end{array}$ \\
\hline $\begin{array}{l}\text { 6months- } \\
\text { 2years }\end{array}$ & 23 & 22 & 45 & \\
\hline 2-6 years & 19 & 21 & 40 & \\
\hline 6-12 years & 4 & 4 & 8 & 0.782 \\
\hline $\begin{array}{l}12-16 \\
\text { years }\end{array}$ & 0 & 1 & 1 & \\
\hline Total & 46 & 48 & 94 & \\
\hline
\end{tabular}

Table II: Age and ligation of processus vaginalis

Similarly, the patients were divided into four categories according to their age. Most of the patients (47.8\%) were between six months to two years (sac ligated in 23 and not ligated in 22). There were 40 patients between two years and six years of which 19 patients underwent ligation of the sac while 21 did not. Patients between six to 12 years were equally distributed in either group (four patients in each group). There was only one patient between 12-16 years enrolled in the study, who eventually didn't undergo sac ligation. However, the results were statistically insignificant ( $p$ value 0.782 ).

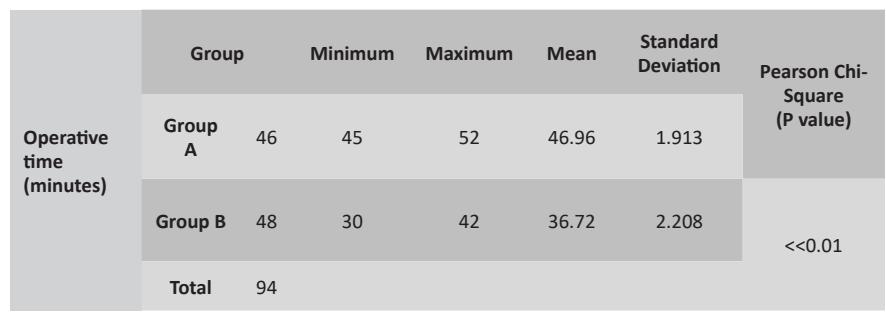

Table III: Operative time and ligation of processus vaginalis

The operative time results were statistically significant ( $p$ value less than 0.01) comparing the groups with patients undergoing sac ligation and patients who did not. The minimum operative time was 45 minutes for patients who underwent sac ligation and 30 minutes for patients who did not undergo sac ligation. The mean operative duration for either groups was $46.96 \pm 1.913$ and $36.72 \pm 2.208$ minutes respectively.

$\begin{array}{lcc} & \text { Group A } & \text { Group B } \\ \text { Complications } & \text { None } & \text { None } \\ \text { Post-operative Hernia } & \text { None } & \text { None }\end{array}$

Table IV: Complications and post-operative hernia with ligation of processus vaginalis

None of the patients had significant post-operative complications or post-operative hernia even after follow up after one, four and eight weeks.

\section{DISCUSSION}

Timely surgery is the mainstay in the definitive management for undescended testis. The recommended age for orchidopexy is between six and nine months because the first sign of degeneration in the testes are identified at about six months of age. Surgery should be performed as soon as possible, if the undescended testis is diagnosed at a later age. ${ }^{12,13}$

Surgery has been the mainstay of treatment for cryptorchidism. For palpable testis found in the inguinal region, standard orchidopexy via inguinal exploration is done. ${ }^{14}$ In the setting of impalpable or abdominal testes, laparoscopic surgery is recommended. Two-stage Fowler-Stephens operation is performed with ligation of the testicular vessels at the initial stage followed by mobilization of the testis based on the collaterals developed from the vas deferens. ${ }^{15}$

Orchidopexy is one of the most common operations performed 
in pediatric patients. First orchidopexy procedure with testicular mobilization, ligation of the hernial sac and fixation of the testis in sub-dartos pouch was described by Bevan in 1899. ${ }^{16}$ Ligation of the hernia sac had been the standard step during orchidopexy until recently when Mohta et al. found in his study that non-ligation of hernia sac had no untoward effect or recurrence of hernia during herniotomy in children. ${ }^{17}$ The study proposed the peritoneal defect closes spontaneously by metamorphosis of the mesodermal cells. A similar study by Shulman et al. who performed hernioplasty in 6321 adults and concluded that ligation of the hernia sac was an unnecessary step. ${ }^{18} \mathrm{Handa}$ et al. conducted a study on 74 patients in a tertiary care hospital in which he proposed that narrowing or closure of the internal ring was not necessary during laparoscopic orchidopexy. Of the total 76 testis, 71 had an adequate length of the spermatic cord which permitted them to be pulled down into the scrotum. No suture was applied to narrow the internal ring. No inguinal hernia was detected on follow up. ${ }^{19}$ Schier in his prospective study of laparoscopic inguinal hernia repair in children proposed that open internal ring was not an inguinal hernia and there was no significant difference when peritoneum was incised and hernia sac resected compared to simple suturing of the sac. ${ }^{20}$ Study by Veena Kumari et al similarly concluded that ligation of hernia sac was unnecessary during orchidopexy. The author conducted a prospective study on 50 children with 38 unilateral and 12 bilateral cases. All the children underwent standard orchidopexy without the ligation of the hernia sac. ${ }^{21}$ Similarly, we found in our study that sac ligation during orchidopexy was unnecessary. In contrast to these studies, we also found that it was more time consuming. Contrary to the above studies, Sonmez K. et al in a retrospective study on 55 children who underwent inguinal orchidopexy concluded that high sac ligation was mandatory to prevent hernia formation and also provided good outcome. ${ }^{22}$

This study was performed to compare the prevalence of postoperative hernia and the operative time with and without sac ligation during orchidopexy in children. Our study showed similar results as the above mentioned studies, that sac ligation was unnecessary during orchidopexy and it also prolonged the operative time. There were no post-operative hernia on regular follow up at one, four and eight weeks. No other complications were noted in any of the case in our study. We also observed that there was no risk of injury to the vas and vessels due to accidental ligation during the procedure. As the sac was not ligated, the testis was easily and appropriately mobilized to the base of the scrotum in comparison to the patients where the sac was ligated.

\section{LIMITATIONS}

The major limitation of the study was the short duration of the study and small sample size. The follow up duration was limited to only 8 weeks. Findings beyond that period was not evaluated. Similarly, the patients enrolled in our study included both premature and term infants.

\section{CONCLUSION}

Ligation of processus vaginalis was unnecessary during orchidopexy and sac ligation consumed more operative time.

\section{REFERENCES}

1. Spitz L, Coran AG. Operative Pediatric Surgery. 6 ed. Euston Road, London: Hodder Arnold; 2006. p. 861-9

2. Ashley RA, Barthold JS, Kolon TF. Cryptorchidism: pathogenesis, diagnosis, treatment and prognosis. UrolClin North Am 2010;37:183-193.

3. Hutson JM, Balic A, Nation T, Southwell B. Cryptorchidism. Semin Pediatr Surg 2010;19:215-224.

4. Elder JS. The undescended testis. Hormonal and surgical management. SurgClin North Am 1988;68:983-1005.

5. Khatwa UA, Menon PS. Management of undescended testis. Indian J Pediatr 2000;67:449-454.

6. Leissner J, Filipas D, Wolf HK, Fisch M. The undescended testis: considerations and impact on fertility. BJU Int 1999;83:885-891.

7. Kolon TF, Herndon CD, Baker LA, Baskin LS, Baxter CG, Cheng $E Y$, et al. Evaluation and treatment of cryptorchidism: AUA guideline. J Urol 2014;192:337-45.

8. British Association of Pediatric Surgeons. Commissioning guide: paediatric orchidopexy for undescended testis. London: Royal College of Surgeons of England (RCS); British Association of Urological Surgeons (BAUS), 2015.

9. Braga LH, Lorenzo AJ, Romao RLP. Canadian Urological Association Pediatric Urologists of Canada (CUA-PUC) guideline for the diagnosis, management, and followup of cryptorchidism. Can Urol Assoc J 2017; 11:E251-60.

10. Radmayr C, Bogaert G, Dogan HS, Kočvara R, Nijman JM, Stein R, et al. EAU Guidelines on Paediatric Urology 2018. Arnhem (The Netherlands): European Association of Urology; European Society for Paediatric Urology, 2018.

11. Hutson JM, Balic A, Nation T, Southwell B. Cryptorchidism. SeminPediatrSurg 2010;19:215-224.

12. Ekwunife OH, Ugwu JO, Onwurah C, Okoli CC, Epundu LK. Undescended Testes: Contemporary Factors Accounting for Late Presentation. African Journal of Urology. 2018;24(3):206-211.

13. Alnoaiji MS, Alrashidi TN, Ghmaird AS, Alsalem SS, Alanazi M, Albazei Al et al. Age at surgery and outcomes of undescended testes at King Salman Armed Forces hospital, Tabuk, Saudi Arabia. Cureus. 2019;11(12):e6413. doi:10.7759/cureus.6413

14. Hodder A. Operative pediatric surgery. $6^{\text {th }}$ ed. An imprint of Hodder Education;2006.

15. Fowler R, Stephens FD: The role of testicular vascular anatomy in the salvage of high undescended testes. Aust NZ J Surg 1959; 29: 92-106.

16. Snyder WH, Van Valin W, Chaffin L. UNDESCENDED TESTES. Calif Med. 1950 Apr;72(4):239-42. PMID: 18731689; 
17. Mohta A, Jain N, Irniraya KP, Saluja SS, Sharma S, Gupta A. Non-ligation of hernial sac during herniotomy: A prospective study. Pediatr Surg Int 2003;19:451-2.

18. Shulman AG, Amid PK, Lichtenstein IL. Ligation of hernial sacA needless step in adult hernioplasty. Int Surg 1993;78:1523.

19. Handa R, Kale R, Harjai MM. Laparoscopic orchiopexy: Is closure of the internal ring necessary? J Postgrad Med 2005;51:266-8.

20. Schier F. An open internal inguinal ring is not an inguinal hernia. Pediatr Surg Int 2007;23:825.

21. Kumari V, Biswas N, Mitra N, Konar H, Ghosh D, Das SK. Is ligation of hernia sac during orchiopexy mandatory?. J Indian Assoc Pediatr Surg 2009; 41: 66-7.

22. Sonmez K, Karabulut R, Turkyilmaz Z, Kaya C, Pehlivan Y, Basaklar AC. For better orchiopexy, processus vaginalis should be dissected and a high ligation should be performed. Rambam Maimonides medical journal. 2016 Jul;7(3):e0020. doi:10.5041/RMMJ.10247. 